Oshora, B., Fekete-Farkas, M., \& Zeman, Z. (2020). Role of Microfinance Institutions in financing Micro and Small Enterprises in Ethiopia. Copernican Journal of Finance \& Accounting, 9(3), 115-130. http://dx.doi.org/10.12775/CJFA.2020.015

\title{
Betgilu Oshora*
}

Szent Istvan University

Maria Fekete-Farkas**

Szent Istvan University

\author{
Zoltan Zeman ${ }^{* * *}$ \\ Szent Istvan University
}

\section{ROLE OF MICROFINANCE INSTITUTIONS \\ IN FINANCING MICRO AND SMALL ENTERPRISES IN ETHIOPIA}

Keywords: access to finance, Ethiopia, microfinance, MSEs.

J E L Classification: G21, M210.

Abstract: Micro and Small Enterprises (MSEs) understood as a means to attain the United Nations 2030 agenda particularly its contribution in reducing the massive unemployment and deep-rooted poverty. Hence, the main aim of this paper is to examine the role of Microfinance Institutions (MFIs) to the survival, value creation and growth of

Date of submission: July 19, 2020; date of acceptance: October 4, 2020.

* Contact information: betgilu2002@gmail.com, Doctoral School of Economics \& Regional Sciences, Szent István University, Gödöllő, Pater K.str.1. H-2100, Hungary, phone: +36706576044; ORCID ID: https://orcid.org/0000-0003-0928-7864.

** Contact information: farkasne.fekete.maria@gtk.szie.hu, Faculty of Economics and Social Sciences, Szent István University, Gödöllő, Pater K.str.1. H-2100, Hungary, phone: +36-28/522-000; ORCID ID: https://orcid.org/0000-0002-6058-009X.

*** Contact information: zeman.zoltan@gtk.szie.hu, Faculty of Economics and Social Sciences Szent István University, Gödöllő, Pater K.str.1. H-2100, Hungary, phone +36-28/522-000; ORCID ID: http://orcid.org/0000-0003-2504-028X. 
MSEs. For this study purpose, secondary data were collected from the National Bank of Ethiopia (NBE) and triangulated with systematic review of empirical evidences. Principal Component Analysis (PCA) was used to examine the relationships and significance in and between the data emerge. The empirical evidences result reveals that unlike banks, MFIs provide diverse micro credit services to address the diverse socio-economic needs of the poor who cannot afford collateral requirement and besides the result from PCA reveals that the economic growth and access to microcredit service by itself is not enough to create more jobs as they are uncorrelated. However, the empirical evidences shows that, the poorest and most vulnerable people are being left behind due to lack of access to finance, poor market linkage and inadequate skill training among many other factors. Therefore, policy-makers have to develop regulatory frameworks that build sound financial institutions and encourage competition among one another.

\section{INTRODUCTION}

The share of the world population living in extreme poverty was reduced from $16 \%$ in 2010 to $10 \%$ in 2015 . However, forecasts recommend that $6 \%$ of the world population will still be living in extreme poverty in 2030, missing the target of ending poverty (United Nations, 2019). Now a-days, unemployment issue has become more serious and even those who are employed also yet live below poverty lines due to lack of decent work. The most recent report by ILO (2019) depicts that, more than one quarter of employed people in low- and middle-income countries were living in extreme or moderate poverty. Despite having a job, $8 \%$ of the world's workers and their families still lived in extreme poverty and the case is worst in sub-Saharan Africa, where the share of working poor stood at 38\% in 2018 (United Nations, 2019). Therefore, being employment does not always guarantee a decent living. Moreover, the unemployment scenario of the youth across the globe is more sever as compared with adults (25 years and older). For instance, the most recent ILO (2020) report reveals that, young people (ages of 15 and 24) are significantly three times as likely to be unemployed as adults and at global level about 68 million young people out of approximately 1.3 billion are unemployed. Moreover, about 126 million $(30 \%)$ of employed youth, remain in extreme or moderate poverty despite having a job (ILO, 2019) while it is understood that youth employment and economic empowerment are essential components of a strong foundation in any society (United Nations, 2018).

MSEs are considered as a crucial tool for the global economic development in reducing unemployment and poverty. For instance, the contribution of formal and informal MSMEs account for $90 \%$ of all firms and on average for 60 - 
$70 \%$ of total employment worldwide and 50\% of GDP (ITC, 2019; World Bank, 2019). However, despite this all contribution to the economy, the most recent report by World Bank (2019) reveals that, $40 \%$ of formal MSMEs in developing countries have an unmet financing need of $\$ 5.2$ trillion every year, which is equivalent to 1.4 times the current level of the global MSME lending. Different empirical evidences across the world such as (ADA, 2017; ITC, 2019; FDRE, 2016; Gebreeyesus, Ambachew, Getahun, Assefa, Abebe, Hassen \& Medhin, 2018; Fowowe, 2017; Dinh, Mavridis \& Nguyen, 2010; Cherkos, Zegeye, Tilahun \& Avvari, 2018; Ključnikov, Majková, Schwendemann \& Knogler, 2016; ITC, 2016) also founds that lack of access to credit is the main constraints for the success of MSEs. Considering the huge contribution in creating job opportunity with relatively low capital, MSEs are identified as one of the priority areas of action among the programs addressing African development (Drbie \& Tilaye, 2013). MSEs are one of the strongest drivers of economic development, innovation and employment (Alhassan \& Sakara, 2014).

MSEs are working towards tackling poverty and finding the decent job for the poor but they are highly facing access to credit service due to high collateral requirements by formal financial institutions. Nowadays, MFIs are given a task force to serve the poor household and those entrepreneurs excluded from the formal financial institutions due to high collateral requirement that they cannot afford. For instance, the study by Bateman (2011); Singla (2014); Umar and Ahmed (2017) found that, microfinance provides small loans to the poor on flexible conditions and through microcredit, poor people can set up their own small business and become able to earn income for their basic needs. Thus, microfinance has been revealed as a key strategy for poverty reduction by improving the living conditions of the poor and 'bottom-up' local economic and social development. Similarly, the study by Helms (2006) and Peprah and Ayayi (2016) reveals that, access to financial services of microfinance can benefit poor and low-income customers increase and stabilize their incomes, build assets, and invest in their own future and permits clients to increase their household expenditure. Despite the promising economic growth in the past decades, Ethiopia is falling behind its peers in the area of provision of credit to the private sector. According to the World Bank's Enterprise Surveys, access to finance is perceived as the main business environment constraint by micro (41\%), small (36\%) and medium (29\%) enterprises in Ethiopia, compared to a Sub-Saharan average of 24\%, 20\% and 16\% respectively (World Bank, 2018). 
The Federal Democratic Republic of Ethiopia (FDRE) government provides both financial and non-financial service to MSEs through MFIs. However, still now lack of access to credit remains the main challenge for the development and expansion of the MSEs. The study by Gebreeyesus et al. (2018) shows that, above $70 \%$ of MSEs had no access to credit from any of the potential external. Moreover, International Finance Corporation (2017) report reveals, in Ethiopia currently there are 136,633 MSMEs with 1,687,733,587 finance supply and $4,290,163,843$ finance gap; and the total of finance gap/GDP account for $7 \%$. This means that it accounts for more than 2.54 times the current level of the country lending. This finance gap is also approximately twice of the global finance gap which is 1.4 for MSMEs (World Bank, 2019).

Based on the above empirical evidences argument, we can understand that, lack of access to credit has been a key challenge constraining the growth of MSEs and hence, the main aim of this study is to examine the role of MFIs in filling the finance gap for MSEs in the case of Ethiopia. Moreover, the paper aims to address:

- The status of MSEs finance gap and the role of MFIs in filling the existing gap;

- The challenges of MSEs in accessing micro credit from MFIs;

- The contribution of MSEs to the country's inclusive economic growth particularly in unemployment reduction.

\section{RESEARCH METHODOLOGY AND THE COURSE OF THE RESEARCH PROCESS}

For this study purpose, secondary data from 2009/10 - 2018/19 time period are extracted from National Bank annual reports and summarized in to excel spreadsheet. To process the data collected, Principal Component Analysis was used by using Minitab 19 software to examine the relationships and significance in and between the data emerge. Empirical evidence from different reports, websites and different scholar findings from publication database like Google Scholar, Research Gates, Academic.edu, Mendeley etc with key words like, access to finance, Ethiopia, microfinance, MSEs were reviewed to develop a comprehensive understanding about the subject of the study. 


\section{OUTCOME OF THE RESEARCH PROCESS}

\section{Role of microfinance in improving the lives of the poor}

In 1976, Muhammad Yunus introduced the concept of microfinance successfully for the first time in Bangladesh to overcome the vicious circle poverty through making small loans to poor families (Umar \& Ahmed, 2017). According to Bateman (2011), microfinance is the provision of micro credit to the poor to help them establish or expand an income-generating activity, and there by escape from poverty. Moreover, Umar and Ahmed (2017) also explained microfinance as a tool to enable poor to start their own business to survive in the society, lift out themselves from poverty, and save something to fulfill their basic needs. Similarly, TIischhauser (2016) and Helms (2006) expressed microfinance as a source of financial services for people lacking access to the financial sector and enables them to take out loans to build or expand businesses and to make savings deposits and invest in their own future.

Despite many achievements over the last decades, microfinance is still a long way to go to extend their service to all who need their service. Helms (2006) identified three major challenges of microfinance from accessing their financial services for the poor: (1) Scaling up quality financial services to serve large numbers of people; (2) Reaching increasingly poorer and more remote people; and (3) Lowering costs to both clients and financial service providers. By serving the poor and working towards the needs of local communities, microfinance has gained recognition at the international stage (Moser \& Gonzalez, 2015). Microfinance program has brought a positive impact on the living conditions of the poor through accessing financial service to the poor and disadvantaged group (Singla, 2014). Moreover, microfinance program also improves access to and control over resources and women's participation in decision-making (Singla, 2014; Nguse, 2019).

Many poor people are served by informal moneylenders, who generally provide easy access to credit but at high cost, charging poor borrowers nominal monthly effective interest rates that typically range from about $10 \%$ to more than 100\% (Oshora, 2016; Robinson, 2001). A key claim for microfinance was that it would help to detach the poor from local loan sharks charging higher interest rates (Bateman, 2011). Moreover, the study made in Vietnam reveals that, micro-credit loans generate positive, significant impacts on household self-employment (Pham \& Lensink, 2008). Microfinance continues to grow, with $\$ 124$ 
billion in world- wide lending and 9.5\% customer growth in 2018. Moreover, in 2018, 139.9 million borrowers benefited from the services of MFIs, compared to just 98 million in 2009 (Microfinance Barometer, 2019).

In Ethiopia, despite the promising economic growth, the finance sector remains under-developed. For instance, in the 2017-18 Global Competitiveness Report, Ethiopia scored 3.4 out of 10, and ranked 109 out of 137 countries in terms of financial market development (International Finance Corporation, 2019). The government provides both financial and non-financial service to MSEs through MFIs. However, still now lack of access to credit remains the main challenge for the development and expansion of the MSEs. According to NBE (2018/19) report, currently there are a total 38 MFIs registered \& operating in Ethiopia with many branches and sub-branch offices. Limited access to finance is a key barrier to economic growth, limiting start-up capital and business expansion. The establishment of MFIs is to fill the existing finance gap to the poor and low-income households.

\section{Challenges of MSEs in accessing microfinance loan service}

Access to finance can promote new-firm entry, growth, innovation, whereas limited access stunts firms' growth (World Bank, 2008). Lending to the poor is quite challenging since the poor's have inadequate resources of which they can use as a collateral, and they are also considered as risky borrowers, and their capacity to repay back the loan is considerably weak and hence they prefer to lend for matured and sustained micro-businesses than younger businesses (Peprah \& Ayayi, 2016; Umar \& Ahmed, 2017). Moreover, it is assumed that lending to the poor is coupled with high transaction cost since the poor tend to borrow the little amount of money hence consuming a lot of loan officers time for minor transactions (Umar \& Ahmed, 2017).

According to the World Bank (2008) investigation report, the poor face two significant problems in obtaining access to credit services. First, they typically have no collateral and cannot borrow against their future income. Second, dealing with small transactions is costly for the financial institutions. Moreover, the study by Armstrong, Davis, Liadze and Rienzo (2013) observed that firm characteristics were the major determinants of credit rationing with firms with a higher credit risk rating, previous financial delinquency and lower sales more likely to be rejected. Similarly, the study made by Becchetti, Garcia, Tro- 
vato and Garcia (2009) noticed that the borrower's past record was significant in determining credit rationing. In addition to this the study by Chakravarty and Shahriar (2010) and Diaz-Serrano and Sackey (2018) observed that respondents who built a longer membership with a micro credit provider and had non-mandatory savings accounts and a track record of payments of previous loans were more likely to apply and be approved. Moreover, education of the borrower, years of experience, gender and age of the borrower were the significant factors in determining credit rationing (Sackey, 2018). Lack of flexible collateral system is also another determinant factor for SMEs to gain access to credit (IFC, 2019).

To overcome the poor households' lack of tangible collateral requirements, microfinance introduced group lending (Helms, 2006; Umar \& Ahmed, 2017). Group-lending schemes improve repayment incentives and monitoring through peer pressure. Likewise, lack of adequate working premises, lack of access to credit and shortage of power supply are the three most important factors impeding the operation of manufacturing MSEs in Ethiopia (Gebreeyesus et al., 2018). Inadequate collateral and difficulties in proving their credit worthiness followed by difficulties in processing loans, and the high cost of borrowing are identified as the main factors that discouraged MSEs from submitting loan applications to formal finance providers. Indeed, collateral rates in Ethiopia are much higher than in many other countries in Africa. For instance, the collateral rates for SSA, Kenya, South Africa, and Morocco were $162.2 \%, 120.8 \%$, $103.8 \%$ and $171.2 \%$ of the loan value respectively, compared to $234 \%$ in Ethiopia (Wolday \& Woldehanna, 2015).

Over the last decade, MFIs are highly engaged in accessing micro credit service to the MSEs but despite increase in the amount of loan the creation of employment were reduced within the same period. Similarly, the PCA also supports this statistical data that there is no correlation between job created and amount of credit provided (refer to figure 3). However, it requires further investigation through the survey method to examine why job creation decreased irrespective of increased amount of the loan. As depicted in figure 1, except the year of 2015/16 that shows decline as compared with the previous year $2014 / 15$, the amount of loan increased over the number of period while the job created within the same period were inversely proportional (refer to figure 2). 
Figure 1. Amount of Credit Provided (in Millions) to MSEs (2009/10-2017/18)

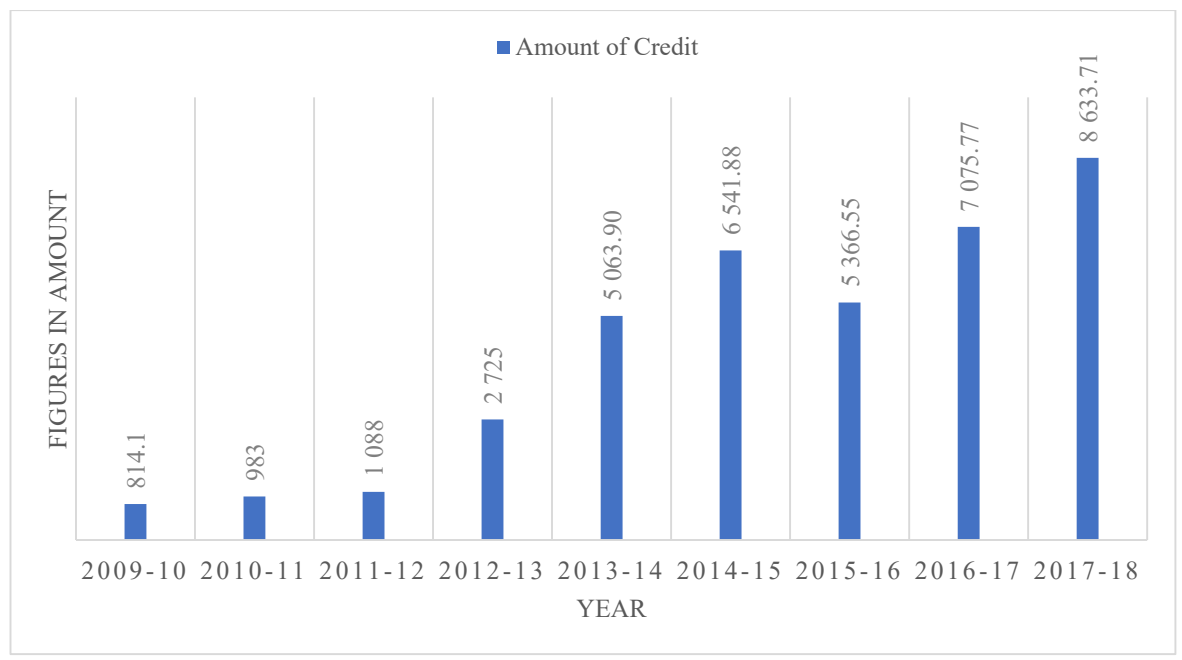

S o u r c e : authors' own processing on the basis of the results of data from NBE Annual Reports.

\section{Role of MSEs in reducing unemployment through microfinance services}

African youth are marginalized and they are not involved in policy formulation and less consulted in the decision-making process and lots of youth energy is invested in stirring-up conflicts and violence. Moreover, employment creation is another formidable challenge that confronts all African countries regardless of their different socio-economic development. In Africa, the youth account for $60 \%$ of total unemployed and three in five of Africa's unemployed are youth (Jalata, 2014). Despite the economic growth in the region, the number of unemployed is expected to grow by nearly 1.9 million by 2020 (ILO, 2019). In addition to limitation of access to credit, the current pandemic expected to hit the growth of the enterprises and it will have a direct influence on its contribution to reducing unemployment. For instance, according to the United Nation Economic Commission for Africa (2020) report, the impact of the pandemic on African economies estimated to slow the growth to $1.8 \%$ in the best case scenario or a contraction of $2.6 \%$ in the worst case. Moreover, it is estimated that due to the result of this decrease in economic growth will have a power to push 5-29 million people below the extreme poverty line ( $\$ 1.90$ per day), about 
19 million jobs lost, between 300,000 and 3.3 million African people could lose their lives as a direct result of COVID-19.

Ethiopian economy has been growing at a remarkable rate for the last several years and it is important to assess how the growth has been translated into more jobs that are of better quality and inclusive. PCA result shows that, there is no significant relationship between economic growth and the number of jobs created (see figure 3). The unemployment statistical data shows that more than $70 \%$ of Ethiopians are under 30 years of age, with urban youth unemployment at $22 \%$ compared to $17 \%$ for all ages. Moreover, more than a quarter of all urban jobs are informal (UNDP, 2018). Similarly, the most recent report by job creation commission shows that unemployment rate in urban areas, meanwhile, reached a level of $19.1 \%$ in 2018 and this is mainly due to the growing rates of urbanization and increase in rural-urban migration (FDRE, 2020).

To overcome the unemployment issue, FDRE has developed a wide-ranging job creation strategy ranging from 2020-2025 with about 2 million new entrants into the workforce each year, and aims to create 14 million jobs by 2025 (IMF, 2020; FDRE, 2020). The main aim of the strategy is to foster the business environment and conditions necessary to create job, to absorb the currently unemployed, and to ensure that jobs are waiting for new entrants to the labor force. In recognition of the vital role MSEs play in the country's economic and social development, much attention has been paid by government to the development of MSEs (FDRE, 2016). For instance, during 2016/17 a total of 157,768 new MSEs were established and created employment for about 1.2 million people through accessing more than Birr 7.1 billion loans to establish and run their business (NBE, 2016/17).

The youths in Ethiopia are still deeply dissatisfied with their daily life due to lack of the assets, and an enabling environment to support their development. Lack of economic opportunities is the primary driver of youth frustration that results in more than $25 \%$ of young people are unemployed (Desta, Bitga \& Boyson, 2018). Many Ethiopian youth spend their day in searching for job despite increase in number of youth graduating from college or university. Educational degrees do not provide access to work and most of the time the youths are working in daily labor jobs despite their education degrees. More importantly, Desta, Bitga and Boyson (2018) also stated out that with a bulge of approximately 30 million young people, the youth claims that their voices are also lacking in community-level decision-making processes and hence could be 
a significant driver of unrest and instability for Ethiopia over the next decade and beyond.

In order to reduce unemployment and create inclusive economic development, the government of Ethiopia is formulating different strategies among which MSEs regarded as a source of lively hood to the poor and unemployed citizen. MSEs constitute a significant portion of the economy and play a central role in job creation through access to microfinance services. For instance, more than $\mathbf{1 1 . 5}$ million people have secured jobs through the successful implementation of MSEs development program for the last one decade. However, from the year 2014/15 to 2017/18 it starts decreasing at increasing rate and this shows that there are many challenges that must be addressed collectively with all stakeholders.

Figure 2. Job Opportunity Created

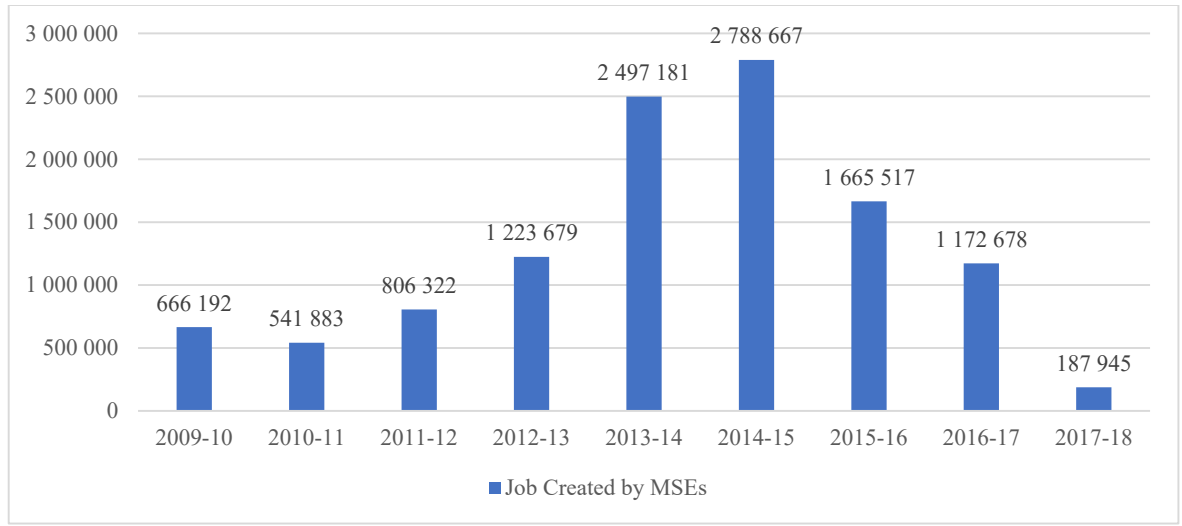

S o u r c e : authors' own processing on the basis of the results of data from NBE Annual Reports.

In Ethiopia for the last five years during the reform period, thousands of young men and women, especially the university and college graduates, come out to the streets in solidarity complaining about massive unemployment, lack of good governance and the high cost of living, demand for jobs and a decent life. Despite the marvelous economic growth achievements over the last decades, there is high increase in unemployment particularly in urban population. The problem of unemployment in Ethiopia is too complicated. Still the question of youth and women is not only to find job, they are facing a challenge in securing 
and retaining the most decent job. Lack of business skills, financing, infrastructure, work premises, preference of dependency on government, preference for paid employment, weak marketing strategies, the desire to make quick profits than making modest profits by producing and selling good quality products and services are among the several challenges inhibit the development of youth and women entrepreneurs (FDRE, 2016). Moreover, the report by FDRE (2020) identified four broad challenges undermine the support provided to MSMEs: (i) poor policy design, (ii) inadequate skill training, (ii) lack of targeted financial support, and (iv) poor market linkages.

\section{PRINCIPAL COMPONENT ANALYSIS RESULT AND DISCUSSION}

We used Principal Component Analysis (PCA) to examine the relationships and significance in and between the data emerge. We assumed that the increase in economic growth and access to credit will result in increase in number of MSEs and hence ultimately contribute for reduction in unemployment. According Kaiser's criterion (most commonly used eigenvalue rule) which considers only factors with an eigenvalue of 1.0 or more, we considered PC1 and PC2 for further investigation since their eigenvalue is greater than one. As depicted in table 1 we can understand that PC1 and PC2 are significant with both Eigenvalues whereas PC3 and PC4 is insignificant with their Eigenvalue. If the eigenvalue of a factor is less than one, it means the component has less information than a single variable and hence PC3 and PC4 are extracted from further investigation. Moreover, the result reveals that the number of MSEs, amount of credit and job created are positively correlated but they are negatively correlated with growth in real GDP in PC1 whereas the components are uncorrelated to each other.

Table 1. Eigenvalue and Eigenvectors PCA Result

\begin{tabular}{|c|c|c|c|c|c|}
\hline \multirow{3}{*}{$\begin{array}{l}\text { Eigenanalysis of the Correlation Matrix } \\
\text { Eigenvalue } 1.97001 .42930 .38000 .2207\end{array}$} & Eigenvectors & & & & \\
\hline & Variable & PC1 & $\mathrm{PC2}$ & $\mathrm{PC} 3$ & PC4 \\
\hline & No of MSEs & 0.664 & 0.082 & -0.003 & 0.743 \\
\hline $\begin{array}{lllll}\text { Proportion } & 0.493 & 0.357 & 0.095 & 0.055\end{array}$ & Amount of Credit(in millions) & 0.449 & -0.550 & 0.617 & -0.338 \\
\hline & Employment & 0.598 & 0.314 & -0.468 & -0.570 \\
\hline 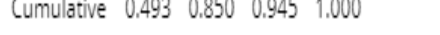 & Growth in Real GDP & 0.007 & 0.769 & 0.633 & -0.088 \\
\hline
\end{tabular}

S o u r c e : authors' own processing. 
There is a positive correlation between the number of MSEs and job created whereas they are negatively correlated with growth in real GDP and amount of the credit (see figure 3). Even though it requires further investigation due to small sample size of time serious data, the PCA tells us that the economic growth and the financial access are not enough to create more jobs as they are negatively correlated.

Figure 3. Loading plot of Number of MSEs, Amount of Credit, Job Created \& Real GDP Rate

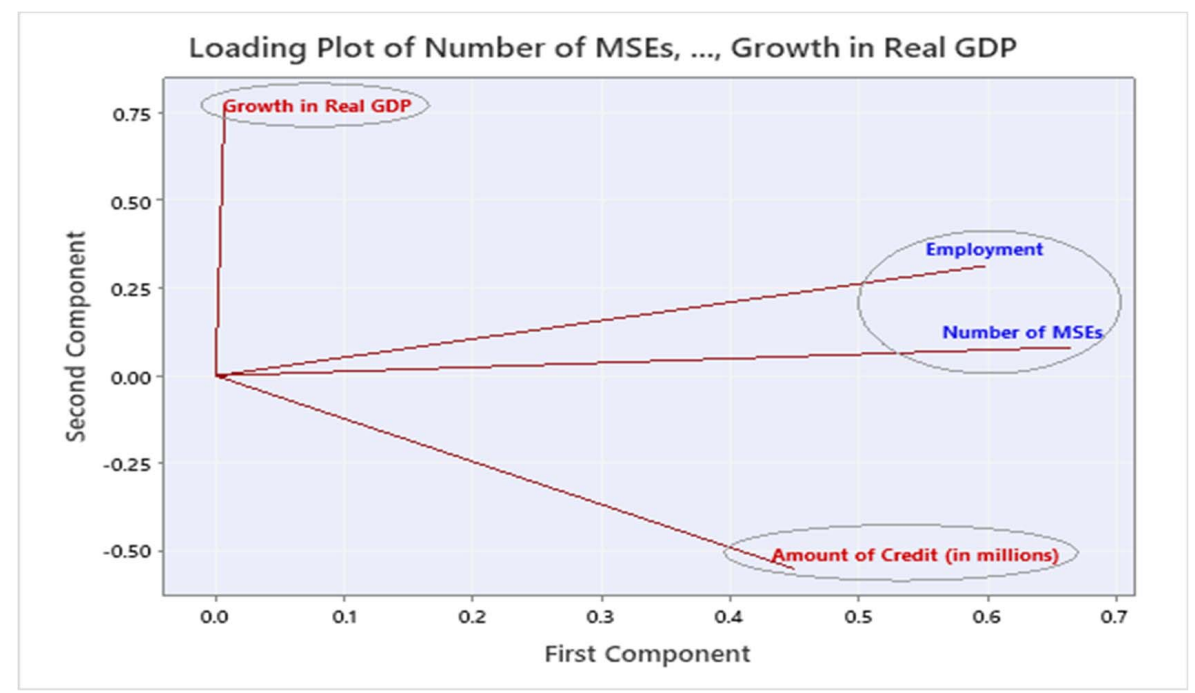

S o u r c e : authors' own processing.

\section{CONCLUSIONS AND POLICY RECOMMENDATIONS}

This paper has investigated the role of MFIs in filling the finance gap for MSEs in the case of Ethiopia. The role of MSEs in reducing unemployment, deep-rooted poverty and hence its contribution to the economic development of the nation has received due attention at global level both in developed and in developing countries. However, as per many literatures reviewed and the secondary data assessed, lack of access to credit were found as the main determinants and hence MFIs are established with the objective to provide both financial and nonfinancial services to support the development of MSEs. Accordingly, our results 
imply that yet now despite the support of MFIs, there is a huge gap between the demand for finance by MSEs and the supply of finance. In contrast, the result from the PCA and the secondary data of loan trend and job created shows that there is no correlation between access to credit and number of job created. And this result contradicts the result of ADA (2017); ITC (2019); FDRE (2016); Fowowe (2017); Dinh et al. (2010); Cherkos et al. (2018); Ključnikov et al. (2016); Gebreeyesus et al. (2018) and ITC (2016) and other empirical evidence across the globe. However, due to limited data available for this study, we could not recommend for hast generalization and hence it needs further study to consider representative sample size and triangulate the evidence of secondary data with primary data through survey method. Therefore, to sustain the contribution of MSEs in poverty and unemployment reduction, there is a need to design and implement effective policy that improve an access to finance (improving MFIs lending capacity and its outreach), demand- driven skill development, local value chain and market linkage. Moreover, improving the business environment for MSEs, by simplifying the bureaucratic and regulatory procedures (particularly access to sheds and lands, and access to electricity and infrastructure) needs due attention by the government and all other stakeholders.

Moreover, the result of the study based on the trend assessment imply that the contribution of MSEs in reducing unemployment is declining from time to time and the dissatisfied youth needs special policy strategy that may incorporate them to participate in the available economic opportunities. The most recent increasing violence and protests across the country may dent investor confidence further and hence, the government must assure the country stability to attract more investment that will create more jobs. Furthermore, given the nature COVID-19 pandemic shock, MSEs may be among most firms exposed to liquidity, thus special facilities to keep lending to small businesses may be appropriate.

\section{REFERENCES}

ADA (2017). Small and Growing Businesses in Ethiopia. Brussels: ADA asbl and First Consult PLC.

Alhassan, F., \& Sakara, A. (2014). Socio-Economic Determinants of Small and Medium Enterprises' ( SMEs ) Access to Credit from the Barclays Bank in Tamale-Ghana. International Journal of Humanities \& Social Science Studies, 1(2), 26-36. 
Armstrong, A., Davis, P., Liadze, L., \& Rienzo, R. (2013). Evaluating Changes in Banking Lending to UK SMEs Over 2001-12. Ongoing Tight Credit? NIESR Discussion Paper, 408, 1-77.

Bateman, M. (2011). Microfinance as a development and poverty reduction policy: is it everything it's cracked up to be? http://www.odi.org/publications/5117-microfinance-development-and-poverty-reduction-policy-it-everything-its-cracked-be.

Becchetti, L., Garcia, M., Trovato, G., \& Garcia, M. (2009). Credit Rationing and Credit View: Empirical Evidence From Loan Date. Credit for Economic and International Studies Research Paper Series, 17, 206-227.

Chakravarty, S., \& Shahriar, A.Z. (2010). Relationship Lending in Microcredit: Evidence from Bangladesh. Purdue University Working Papers, 1005, 1-45.

Cherkos, T., Zegeye, M., Tilahun, S., \& Avvari, M. (2018). Examining significant factors in micro and small enterprises performance: case study in Amhara region, Ethiopia. Journal of Industrial Engineering International, 14(2), 227-239. http://dx.doi. org/10.1007/s40092-017-0221-y.

Desta, Z.F., Bitga, A., \& Boyson, J. (2018). Usaid/Ethiopia Cross-Sectoral Youth Assessment Situational Analysis. Washington: USAID's YouthPower.

Diaz-Serrano, L., \& Sackey, F.G. (2018). Microfinance and credit rationing: Does the microfinance type matter? Journal of Sustainable Finance and Investment, 8(2), 114-131. http://dx.doi.org/10.1080/20430795.2017.1403181.

Dinh, H.T., Mavridis, D.A., \& Nguyen, H. B. (2010). The Binding Constraint on the Growth of Firms in Developing Countries. Policy Research Working Paper, 5485. http:// dx.doi.org/10.1596/9780821396322_ch04.

Drbie, M., \& Tilaye, M.B.A. (2013). Deterrents to the Success of Micro and Small Enterprises in Akaki-Kality Sub-City. Journal of Business and Administrative Studies, 5(2), $1-34$.

FDRE (2016). Federal Democratic Republic of Ethiopia Volume I: Growth and Transformation Plan II (GTP II), http://ethiopia.un.org/en/15231-growth-and-transformation-plan-ii.

FDRE (2020). Sustainable Jobs for All: Plan of Action for Job Creation (2020-2025), Brifing document by Job Creation Comission Ethiopia, http://www.jobscommission. gov.et/wp-content/uploads/2019/11/National-Plan-for-Job-Creation-Brief.pdf.

Fowowe, B. (2017). Access to finance and firm performance: Evidence from African countries. Review of Development Finance, 7(1), 6-17. http://dx.doi.org/10.1016/j. rdf.2017.01.006.

Gebreeyesus, M., Ambachew, A., Getahun, T., Assefa, B., Abebe, G., Hassen, S., \& Medhin, H. (2018). Main Features of Micro and Small Manufacturing Enterprises in Ethiopia. Addis Ababa: Ethiopian Development Research Institute.

Helms, B. (2006). Building Inclusive Financial Systems. Washington: World Bank Group. http://dx.doi.org/10.1596/978-0-8213-6360-7.

IFC (International Finance Corporation) (2017). MSME Finance Gap: Assessment of the Shortfalls and Opportunities in Financing Micro, Small, and Medium Enterprises in Emerging Markets. Washington: World Bank Group. 
ILO (2019). World Employment Social Outlook: Trends 2019. Geneva: International Labour Office.

ILO (2020). Global Employment Trendsfor Youth 2020: Technology and the Future of Jobs. Geneva: International Labour Office.

IMF (2020). The Federal Democratic Republic of Ethiopia: 2019 Article IV Consultation and Requests for Three-Year Arrangement under the Extended Credit Facility and an Arrangement under the Extended Fund Facility-Press Release and Staff Report. Pretoria: International Monetary Fund. African Dept.

ITC (2016). SME Competitiveness In Ghana Alliances For Action in Ghana. Geneva: ITC.

ITC (2019). SME Competitiveness Outlook 2019: Big Money for Small Business. Financing the Sustainable Development Goals. Geneva: ITC.

Jalata, G.G. (2014). Challenges and Opportunities of Youth in Africa. US-China Foreign Language, 12(6), 537-542. http://dx.doi.org/10.17265/1539-8080/2014.06.009.

Ključnikov, A., Majková, M.S., Schwendemann, A., \& Knogler, C. (2016). Do SMEs in slovakia face real difficulties in obtaining financing? Comparison of the studies from Slovakia and the EU. Journal of International Studies, 9(3), 36-52. http://dx.doi. org/10.14254/2071-8330.2016/9-3/3.

Microfinance Barometer (2019). A Look Back at the Trends in Microfinance, http://www. convergences.org/wp-content/uploads/2019/09/Microfinance-Barometer-2019_web $-1 . p d f$.

Moser, R.M.B., \& Gonzalez, L. (2015). Green Microfinance: A New Frontier to inclusive financial services. Revista de Administração de Empresas, 56(2), 242-250. http:// dx.doi.org/10.1590/S0034-759020160209.

NBE (2016/17). National Bank of Ethiopia Annual Report. Addis Ababa: NBE.

NBE (2018/19). National Bank of Ethiopia Annual Report. Addis Ababa: NBE.

Nguse, T. (2019). Role of Microfinance Institutions on Women Empowerment in case of Wisdom Microfinance Institution, Dilla Town - Ethiopia. Journal of Advanced Research in Technology and Management Sciences, 1(4), 1-7.

Oshora, B. (2016). Independent Variable Impact on Loan Repayment Default in Omo Microfinance Institution - Konso Woreda. International Journal of Management, IT \& Engineering, 6(10), 79-96.

Peprah, J.A., \& Ayayi, A.G. (2016). Return to Micro-credit on Small-scale Businesses: A Case Study of Ghanaian MFI. Journal of International Development, 28(4), 606-622. http://dx.doi.org/10.1002/jid.3139.

Robinson, M.S. (2001). The Microfinance Revolution: Sustainable Finance for the Poor. Washington: World Bank Group.

Sackey, F.G. (2018). Borrower-lender relationship and access to commercial banks' credit market. Journal of Sustainable Finance and Investment, 9(1), 33-44. http:// dx.doi.org/10.1080/20430795.2018.1507130.

Singla, M.L. (2014). Microfinance and economic development in India: Growth and challenges. International Journal of Research in Finance and Marketing, 4(3), 1-13.

TIischhauser, K. (2016). Microfinance Market Outlook. Developments, Forecasts, Trends. Zurich: ResponsAbility Investments AG. 
Tra Pham, T.T., \& Lensink, R. (2008). Household Borrowing in Vietnam: A Comparative Study of Default Risks of Formal, Informal and Semi-formal Credit. Journal of Emerging Market Finance, 7(3), 237-261. http://dx.doi.org/10.1177/097265270800700302.

Umar, M., \& Ahmed, W. (2017). The Role of Microfinance on Poverty Alleviation and Its Impacts on People and Society: Evidence From the Grameen Bank. Journal of Poverty, Investment and Development, 38, 7-13.

United Nation Economic Commision for Africa (2020). COVID-19 in Africa: Protecting Lives and Economics. Addis Ababa: Economic Commission for Africa.

United Nations (2018). World Youth Report: Youth and the 2030 Agenda for Sustainable Development. New York: United Nations.

United Nations (2019). A Concise Encyclopedia of the United Nations. Leiden: Brill Publishers. http://dx.doi.org/10.1163/ej.9789004180048.i-962.115.

United Nations Development Programme (UNDP) (2018). National Human Development Report: Industrialization with a Human Face. New York: UNDP.

Wolday, A., \& Woldehanna, T.W. (2015). Access to finance: A tool to improve the performance of youthowned MSEs in Ethiopia.

World Bank; International Finance Corporation (2019). Creating Markets in Ethiopia: Sustaining Progress Towards Industrialization. Washington: World Bank Group.

World Bank (2008). Finance for All? Policies and Pitfalls in Expanding Access. Washington: World Bank Group.

World Bank (2018). Disruptive Finance: Using Psychometrics to Overcome Collateral Constraints in Ethiopia. Washington: World Bank Group. 